\title{
A THERAPEUTIC APPROACH TO LOW-GRADE SEROUS OVARIAN CARCINOMA
}

\author{
BRANKA PETRIĆ MIŠE ${ }^{1}$ and DINKA ŠUNDOV² \\ ${ }^{1}$ Department of Oncology, University Hospital Split and School of Medicine Split, Split, Croatia \\ ${ }^{2}$ Department of Pathology, Forensic Medicine and Cytology, University Hospital Split \\ and School of Medicine Split, Split, Croatia
}

\begin{abstract}
Summary
Low-grade serous ovarian cancer (LGSOC) has less aggressive behavior and a better clinical outcome than high-grade serous ovarian cancer (HGSOC). Considering that this malignancy is relatively chemoresistant, surgery is the keystone of treatment, with a strong recommendation for maximal cytoreduction. Women with stage IA-IB disease should undergo observation alone after primary cytoreductive surgery. In contrast, observation, chemotherapy, or endocrine therapy are possible options for those with stage IC-IIA disease. Patients with stage IIB-IV disease receive either chemotherapy with carboplatin and paclitaxel for six cycles followed by endocrine therapy, most commonly with aromatase inhibitors, or endocrine therapy alone until disease progression or unacceptable toxicity. Surgery, chemotherapy, and endocrine therapy are also used in patients with recurrent disease. Targeted agents, especially mitogen-activated protein kinase (MEK) inhibitors and cyclin-dependent kinase (CDK) inhibitors, are currently under evaluation in this clinical setting. Additional research on the genomics of LGSOC to better define the activating gene mutations involved in the carcinogenesis is strongly warranted to improve the prognosis with this malignancy.
\end{abstract}

KEYWORDS: LGSOC, chemotherapy, endocrine therapy, targeted therapy

Low-grade serous ovarian carcinoma (LGSOC) accounts for approximately $5-10 \%$ of serous epithelial ovarian cancers with a unique molecular profile and clinical course (1). It is characterized by younger age at presentation, less aggressive biological behavior, lower sensitivity to chemotherapy, and longer overall survival (OS) compared with high-grade serous ovarian carcinoma (HGSOC) (2). Most LGSOC arise in a slow stepwise fashion from a serous cystadenoma or adenofibroma, which progresses to the ovary's serous borderline tumor (SBT). Up to $7 \%$ of women with SBT develop subsequent carcinoma. Risk factors for the development of carcinoma include mi-

Corresponding author: Branka Petrić Miše, Department of Oncology, University Hospital Split and School of Medicine Split, Split, Croatia, Soltanska 2, 21000 Split, Croatia. email:brapemi@gmail.com cropapillary/cribriform subtype, bilateral disease, ovarian surface involvement, advanced stage, and residual disease after surgery. On histology, LGSOC is characterized by small nests, glands, papillae or micropapillae and inverted macropapillae, frequently free-floating within unlined clear spaces, low-grade cytological atypia $(<3$-fold variation in nuclear size), and low mitotic activity (3).

Estrogen receptors (ERs) and progesterone receptors (PRs) are expressed more frequently in LGSOC than in HGSOC (4). LGSOC often harbors activating mutations of genes involved in the mitogen-activated protein kinase (MAPK) pathway, such as KRAS, BRAF, ERBB2, and NRAS. Sometimes it presents driver mutations of PIK3CA, FFAR1, USP9X, and EIF1AX linked to the AKTmTOR pathway (5). Compared with HGSOC, LGSOCs have overexpression of insulin-like growth 
factor-1 (IGF-1) and a much lower frequency of p53 and BReast CAncer (BRCA) gene mutations $(6,7,8)$.

\section{TREATMENT OPTIONS FOR LOW-GRADE SEROUS OVARIAN CARCINOMA}

\section{Surgery}

Primary surgery is the cornerstone of the treatment of LGSOC $(9,10)$. Patients with disease confined to the ovaries should undergo bilateral salpingo-oophorectomy, total hysterectomy, and comprehensive peritoneal and retroperitoneal staging. Fertility-sparing surgery, including unilateral salpingo-oophorectomy, surgical staging, and endometrial biopsy, could be taken for young women with stage IA-IC1 disease who strongly desire to preserve their childbearing potential $(9,10,11)$. Patients with advanced disease should undergo primary debulking surgery (PDS) to remove all macroscopically detectable disease $(9,10)$.

In the GOG 182 trial, comparing carboplatin and paclitaxel versus combination with triplet or sequential doublet regimens, ancillary analysis assessed survival in 189 patients with FIGO stage III-IV LGSOC. The median age was 56.5 years, and $87.3 \%$ had stage III disease. The median follow-up time was 47.1 months. The women with no gross residual disease after PDS had better progressionfree survival (PFS) (median, 33.2 months) and OS (median, 96.9 months) compared with those with residual disease $0.1-1.0 \mathrm{~cm}$ (14.7 months and 44.5 months, respectively) and those with residual disease $>1.0 \mathrm{~cm}$ (14.1 months and 42.0 months, respectively) (PFS, $P<0.001$; OS, $P<0.001$ ). Surgical cytoreduction to microscopic residual was associated with improved PFS and OS in women with advanced-stage LGSOC (12). Bogati et al. conducted a retrospective case series of women affected by advanced stage (IIIB or more) LGSOC undergoing surgery in a single Italian oncologic center between January 2000 and December 2017. Primary cytoreductive surgery was performed in 68 of 72 patients $(94 \%)$ with FIGO stage IIIB-IV LGSOC and achieved no residual disease in 44 patients, residual disease $<1.0 \mathrm{~cm}$ in 49 patients, and residual disease $>1.0 \mathrm{~cm}$ in 19 patients. Multivariate analysis showed that non-optimal cytoreduction was an independent poor prognostic factor for recurrence risk (HR 2.79; $P=0.021$ ). According to multivariate analysis, the absence of significant comorbidities (HR 0.56; $P=0.093$ ) and primary instead of interval debulking surgery (IDS) (HR 2.95; $P=0.027$ ) were independently associated with improved overall survival (13).

Secondary cytoreductive surgery (SCS) has a role in managing recurrent LGSOC $(14,15)$. A retrospective study of Johns Hopkins Medical Institutions assessed 26 patients with ovarian micropapillary serous carcinoma, of which 21 underwent SCS and $15(71 \%)$ achieved an optimal cytoreduction (residual disease $<$ or $=1.0 \mathrm{~cm}$ ) $(14)$. Bristow et al. showed a single institution retrospective trial of patients with recurrent low-grade serous carcinoma who underwent SCS between 1995 and 2012. Forty-one patients met the inclusion criteria. The median time between primary tumor debulking and SCRS was 33.2 months. Of 41 eligible patients who underwent SCS, 32 (78\%) had the gross residual disease after completing secondary surgery. The median PFS for patients with no gross residual disease after SCS was 60.3 months, compared to 10.7 months for patients with gross residual disease $(P=0.008)$. Median OS for patients with no gross residual disease was 93.6 months compared to 45.8 months $(P=0.04)$. These results confirmed a benefit to optimal SCS in patients with recurrent low-grade serous carcinoma (15).

\section{Chemotherapy}

LGSOC is indolent neoplasia less responsive to chemotherapy both in first-line and in the recurrent setting than HGSOC $(16,17)$. A preclinical study showed that LGSOC was quite resistant to paclitaxel, cisplatin, carboplatin, cyclophosphamide, gemcitabine, and less likely to be resistant to etoposide, doxorubicin, and topotecan (18). Metaanalysis of four AGO-OVAR phases III trials, including patients with FIGO stage IIIB-IV ovarian carcinoma who underwent PDS followed by platinum/paclitaxel based regimens, identified 145 patients with LGSOC, of which 39 had residual disease $>1.0 \mathrm{~cm}$ and were evaluated for response to chemotherapy. An objective response was obtained in 10 patients $(23 \%)$, and the response rate was significantly lower compared to the $90 \%$ response rate in 80 women with HGSOC with residual disease $>$ $1.0 \mathrm{~cm}(P<0.001)(16)$. Gershenson et al. demonstrated that $62 \%$ of women with primary LGSOC treated with standard platinum-based chemothera- 
py had persistent disease at the time of second-look surgery (19). The response rate to platinum-based chemotherapy is significantly lower in women with advanced LGSOC than women with HGSOC. Only $23 \%$ of patients with suboptimally debulked disease responded to adjuvant platinum-based chemotherapy (17).

\section{Endocrine therapy}

Endocrine therapy may provide clinical benefit in women with LGSOC $(4,20,21,22,23)$. Escobar et al. found $\mathrm{ER}+/ \mathrm{PR}+$ in $21.8 \%, \mathrm{ER}+/ \mathrm{PR}-$ in $17.4 \%$, ER-/PR+ in $13.0 \%$, and ER-/PR- in $47.8 \%$ of 27 LGSOCs and assumed that only the subset of tumors with double steroid receptor expression could benefit from endocrine treatment (4).

Gershenson et al. analyzed 203 patients with FIGO stage II-IV LGSOC after primary cytoreductive surgery and platinum-based chemotherapy. They were randomized in two arms: by endocrine therapy in 70 cases and observation in 133 cases. Endocrine therapy consisted of letrozole in 38 cases $(54.3 \%)$, anastrozole in $2(2.9 \%)$, tamoxifen in 20 $(28.6 \%)$, leuprolide acetate as single agent or in combination in $9(12.9 \%)$, and medroxyprogesterone acetate in $1(1.4 \%)$ case. Patients who had maintenance endocrine therapy had better PFS (median, 64.9 versus 26.4 months, $P<0.001$ ) than those who had not. Median OS was similar in the two groups (115.7 months versus 102.7 months, $P=$ 0.42) (20). A retrospective study of Johns Hopkins School of Medicine, Cleveland Clinic, and Memorial Sloan Kettering Cancer Center assessed 27 patients with FIGO stage II-IV LGSOC who underwent either PDS (26 patients) or neoadjuvant carboplatin/paclitaxel-based chemotherapy plus IDS (1 patient) followed by endocrine therapy, consisting of letrozole $(55.5 \%$ of cases), anastrozole $(37.1 \%)$ or tamoxifen $(7.4 \%)$. Six $(22.2 \%)$ patients relapsed after a median time of 21.5 months, 3-year PFS was $79.0 \%$, and 3-year OS was $92.6 \%$ (21). Watson reported a case report with three years durable response to letrozole in a 46-year-old patient with rapidly progressive estrogen receptor-positive low-grade serous ovarian cancer (22).

A randomized phase III trial compares six cycles of carboplatin/paclitaxel chemotherapy followed by maintenance letrozole versus letrozole monotherapy after PDS in women with stage II-IV LGSOC (NRG-GY-019). The findings from this study will hopefully provide definitive therapy for women with newly diagnosed LGSOC.
The MD Anderson Cancer Center analyzed 64 patients who received different hormone regimens for recurrent LGSOC. There were six complete responses and two partial responses, for an overall response rate of $9.0 \%$ in the entire cohort, $2.7 \%$ in platinum-resistant patients, and $13.5 \%$ in platinum-sensitive patients. The objective responses were achieved in six of the 33 cases $(18.2 \%)$ treated with letrozole, one of the $21(4.8 \%)$ treated with anastrozole, one of the $17(5.9 \%)$ treated with tamoxifen, none of the 14 treated with leuprolide alone or combined with other agents, and none of the four treated with fulvestrant, megestrol acetate or raloxifene. The median to progression was 7.4 months in the entire cohort, 8.9 months in patients with $\mathrm{ER}+/ \mathrm{PR}+$ disease, and 6.2 months in those with ER+/PR- disease (23). Anastrozole has achieved 3-month clinical benefit (partial response + stable disease) in $23(63.9 \%)$ and a 6-month clinical benefit in $21(60.8 \%)$ of the 36 post-menopausal women with ER+ and/or PR+ recurrent/metastatic LGSOCs. The median PFS was 11.1 months (24).

\section{Targeted therapy}

Based on preclinical research findings, potential genes or pathways for targeting low-grade serous carcinoma include the angiogenesis pathway, MAPK pathway, receptor for insulin-like grow factor-1 (IGFR-1), and possibly the PI3K/ $\mathrm{AKT} / \mathrm{mTOR}$ pathway $(9,25)$.

\section{Bevacizumab}

For all epithelial ovarian cancers, prospective clinical trials have demonstrated improved outcomes for women treated with bevacizumab in the front-line setting, in the platinum-sensitive relapsed setting, and the platinum-resistant relapsed setting $(26,27,28,29)$. Although there have not been any prospective clinical trials specifically for women with low-grade serous carcinoma, a few retrospective series have been reported.

Bidus et al. reported three patients with apparent recurrent low-grade serous carcinomas treated with bevacizumab. All three patients experienced a sustained response, two partial responses, and one complete response (30). In 2010, Schmeler et al. reported experience in treating 17 women with recurrent low-grade serous carcinoma with bevacizumab. Of 13 patients with measurable disease, five had a partial response, and 
three had stable disease (31). A retrospective study of Memorial Sloan Kettering Cancer Center showed that bevacizumab combined with chemotherapy offers a treatment strategy for patients with low-grade serous ovarian cancer. Of 17 patients, 15 were evaluable for the primary endpoint of the best overall response. Two patients were treated with bevacizumab as a single agent, and the remainder received bevacizumab in combination with chemotherapy (paclitaxel, topotecan, cyclophosphamide, gemcitabine, or gemcitabine and carboplatin). The median duration of bevacizumab administration was 23 weeks. There were no complete responses. Partial responses were observed in 6 patients ( 5 received concurrent paclitaxel, and 1 received concurrent gemcitabine). The overall response rate was $40 \%$. This study is limited by small numbers and heterogeneous treatment schedules regarding bevacizumab dosing and concomitant therapies. Bevacizumab was administered at different doses $(15 \mathrm{mg} / \mathrm{kg}, 10 \mathrm{mg} / \mathrm{kg}$, or $7.5 \mathrm{mg} / \mathrm{kg}$ ). Responses were seen in patients treated with each of these doses. No responses were seen with bevacizumab as a single agent (32). Rose et al. retrospectively analyzed 12 patients with LGSOC with bevacizumab as a single agent (11 patients) or in a combination regimen (1 patient). Only one patient achieved a partial response, but three patients had stable disease after progression-free intervals on prior chemotherapy of 2.5, 4, and 7 months, respectively. Ten of the 11 patients were progression-free at six months. The median PFS was 48 months. These results showed that patients with LGSOC treated primarily with bevacizumab as a single agent have a low response rate but very long PFS (33).

Another retrospective trial of MD Anderson Cancer Center analyzed 45 patients with pretreated recurrent LGSOC who received bevacizumab from 2007 to 2016. Of the 45 patient-regimens, 40 were evaluable for a response, while five patients had no measurable disease. Only three patients received bevacizumab as a single agent. The median number of prior regimens was 4 . The average duration of bevacizumab treatment was four months. Study endpoints included the best response, median progression-free survival, median overall survival, and toxicity. Complete response was seen in 7,5\%, partial response in $40 \%$ patients (16 patients), and $30 \%$ of patients (12 patients) had stable disease. Disease progression was seen in
22,5\% (9 patients). The median PFS was 10.2 months. The median OS was 34.6 months. Fifteen patients discontinued bevacizumab related to toxicity. Bowel perforation and entero-cutaneous fistula occurred in three patients (34).

\section{MEK inhibitors}

The high prevalence of MAPK pathway alterations in LGSOC has stimulated the evaluation of selective MEK inhibitors in patients with this malignancy $(9,35)$.

Selumetinib was investigated in a phase II trial given ( $50 \mathrm{mg}$ twice daily orally) to 52 patients with recurrent LGSOC. A complete response was seen in one patient, and a partial response was achieved in seven patients. The objective response rate was $15 \%$, and stable disease was observed in 34 patients. The response to selumetinib was not related to RAS/RAF mutational status. The median time to response was 4.8 months, the median duration of response was 10.5 months, and the median PFS was 11 months. The most frequent adverse events in grade 3 were gastrointestinal and dermatologic toxicity (36).

The MILO/ENGOT-ov11, phase III study randomized patients with recurrent or persistent LGSOC to receive either binimetinib or physician's choice chemotherapy (PCC) (liposomal doxorubicin, paclitaxel, topotecan), was prematurely closed due to futility. Median PFS was 9.1 months for binimetinib and 10.6 months for PCC by blinded independent central review (HR 1.21, $P=0.807)$. The ORR by BIRC was $16 \%$ for binimetinib and $13 \%$ for PCC. In the updated analysis, the ORR by local investigator assessment was $24 \%$ in both groups (37).

Another trial, GOG 0281, was a phase II/III trial that investigated trametinib versus PCC (pegylated liposomal doxorubicin or weekly paclitaxel, topotecan, letrozole, or tamoxifen) for patients with recurrent or progressive LGSOC. The patient population was pretreated; $48 \%$ of patients had at least three prior systemic regimens. Controversy to MILO trial, GOG 0281 met its primary endpoint, with a median PFS of 13.0 months for trametinib and 7.2 months for PCC (HR 0,48, $P<0,001)$. The ORR was $26 \%$ for trametinib and $6,2 \%$ for PCC, respectively. GOG 0281 was the first positive randomized trial with MEK inhibitor in women with recurrent LGSOC (38). Fernandez et al. compared four different MEK inhibitors (tra- 
metinib, selumetinib, binimetinib, and refametinib) in novel LGSOC patient-derived cell lines and found trametinib to have the greatest antiproliferative effects. A single dose of trametinib had a more significant impact on cellular proliferation than 10-fold higher doses of the other drugs (39).

Preclinical and clinical trials have confirmed an association between KRAS mutation status and response to MEK inhibitors. Although not meeting its primary end point, the MILO study demonstrates that MEK inhibition results in disease control in a significant number of patients and is a strategy that should be seriously considered in this difficult-to-treat disease. More importantly, there are questions still to be answered regarding the extent to which various MAPK mutations confer MEK inhibitor sensitivity (35).

Metformin decreases insulin production, insulin growth factor-1 (IGF-1), and vascular endothelial growth factor, and therefore it exerts antimitotic and anti-angiogenetic effects. In vitro studies showed that metformin inhibited all LGSOC cell lines. In contrast, trametinib with metformin significantly inhibited the growth of RASmutated LGSOC cell lines but not of cells without RAS mutation. Therefore, metformin alone or in combination with MEK inhibitors could help manage LGSOC (40).

\section{CDK4/6 inhibitors}

Endocrine therapy resistance remains a major clinical challenge, as patients ultimately succumb to progressive disease. New therapeutic strategies that synergize with endocrine therapies are needed to overcome resistance and potentially prolong patient survival (41).

Cyclin dependent kinase 4 and 6 inhibitors (ribociclib, palbociclib and abemaciklib) has been approved by the Food and Drug Administration (FDA) and the European Commission as initial endocrine-based therapy for postmenopausal women with hormone receptor-positive, human epidermal growth factor receptor 2 negative advanced breast cancer in combination with an aromatase inhibitor following a randomized phase III trial $(42,43,44)$.

A phase II study found that ribociclib and letrozole combined showed promising activity in patients with estrogen receptor-positive ovarian cancer and endometrial cancer. The highest benefit was observed in low-grade serous ovarian cancers (45). A phase II study is currently assessing the combination of letrozole and ribociclib in women with recurrent LGSOC. The primary outcome measure is the response rate. Secondary outcome measures are clinical benefit rate, toxicity, PFS and OS, ER and PR expression, mutation analysis of genomic signatures, and Ki-67 expression. These biological variables will be correlated with response and clinical benefit. A pilot phase II study of neoadjuvant fulvestrant plus abemaciclib every four weeks is ongoing in patients with stage III-IV LGSOC. The primary endpoint is the clinical benefit rate after four cycles of treatment (9).

\section{CONCLUSION}

Low-grade serous carcinoma may occur de novo or following a diagnosis of a serous tumor of low malignant potential. A young age characterizes it at diagnosis, relative chemoresistance, and prolonged survival compared with HGSOC. Initial surgical treatment is a primary procedure. While platinum/taxane chemotherapy remains standard as first-line systemic therapy, there is a need for studying new strategies. For recurrent tumors, secondary cytoreduction provides benefit in selected patients. Options for systemic therapy management include chemotherapy, hormonal therapy, or targeted agents. Targeted therapies, primarily bevacizumab, MEK inhibitors, and CDK inhibitors, alone or in combination with other antitumor therapy, are in the focus of several ongoing and future clinical trials. Additional research on the genomics of LGSOC, to better define the activating gene mutations involved in the carcinogenesis is strongly warranted to improve this malignancy prognosis.

\section{REFERENCES}

1. Gershenson DM, Sun CC, Lu KH, Coleman RL, Sood AK, Malpica A, et al. Clinical behavior of stage II-IV low-grade serous carcinoma of the ovary. Obstet Gynecol. 2006;108:361-8.

2. Schlumbrecht MP, Sun CC, Wong KN, Broadus RR, Gershenson DM, Bodurka DC. Clinicodemographic factors influencing outcomes in patients with lowgrade serous ovarian carcinoma. Cancer. 2011;117:3741-9.

3. WHO Classification of Tumours Editorial Baord. Female genital tumours. 5th ed. Lyon: IARC; 2020:32-44.

4. Escobar J, Klimowicz AC, Dean M, Chu P, Nation JG, Nelson GS, et al. Quantification of ER/PR expression 
in ovarian low-grade serous carcinoma. Gynecol Oncol. 2013;128:371-6.

5. Hunter SM, Anglesio MS, Ryland GL, Sharma R, Chiew YE, Rowley SM, et al. Molecular profiling of low grade serous ovarian tumors identifies novel candidate driver genes. Oncotarget. 2015;6:37663-77.

6. King ER, Zu Z, Tsang YTM, Deavers MT, Malpica A, Mok SC, et al. The insulin-like growth factor 1 pathway is a potential therapeutic target for low-grade serous ovarian carcinoma. Gynecol Oncol. 2011;123:138.

7. Singer G, Stöhr R, Cope L, Dehari R, Hartmann A, Cao D.F, et al. Patterns of p53 mutations separate ovarian serous borderline tumors and low- and high-grade carcinomas and provide support for a new model of ovarian carcinogenesis: a mutational analysis with immunohistochemical correlation. Am J Surg Pathol. 2005;29:218-24.

8. Vineyard MA, Daniels MS, Urbauer DL, Deavers MT, Sun CC, Boerwinkle E, et al. Is low-grade serous ovarian cancer part of the tumor spectrum of hereditary breast and ovarian cancer? Gynecol Oncol. 2011;120:229-32.

9. Gadducci A, Cosio S. Therapeutic approach to lowgrade serous ovarian carcinoma: state of art and perspectives of clinical research. Cancers. 2020;12:1336.

10. National Comprehensive Cancer Network - Clinical Practise Guidelines in Oncology - Ovarian cancer including fallopian tube cancer and primary peritoneal cancer NCCN guidelines, version 1.2020 - 26 june 2020 [cited 2020 October 13th]. Available from: https:// www.nccn.org/professionals/physician_gls/pdf/ovarian_blocks.pdf.

11. Bentivegna E, Gouy S, Maulard A, Pautier P, Leary A, Colombo N, et al. Fertility-sparing surgery in epithelial ovarian cancer: a systematic review of oncological issues. Ann Oncol. 2016;27:1994-2004.

12. Fader AN, Java J, Ueda S, Bristoe RE, Armstrong DK, Bookman MA, et al. Gynecologic Oncology Group (GOG). Survival in women with grade 1 serous ovarian carcinoma. Obstet Gynecol. 2013;122:225-32.

13. Bogani G, Maggiore ULR, Paolini B, Diito A, Martinelli F, Lorusso D, et al. The detrimental effect of adopting interval debulking surgery in advanced stage low-grade serous ovarian cancer. J Gynecol Oncol. 2019;30,e4

14. Bristow RE, Gossett DR, Shook DR, Zahurak ML, Tomacruz RS, et al. Recurrent micropapillary serous ovarian carcinoma. Cancer. 2002;95:791-800.

15. Crane ES, Sun CC, Ramirez PT, Schmeler KM, Malpica A, Gershenson DM. The role of secondary cytoreduction in low-grade serous ovarian cancer or peritoneal cancer. Gynecol Oncol. 2015;136:25-9.

16. Grabowski JP, Harter P, Heitz F, Traut A, Pfisterer J, $\mathrm{du}$ Bois A, et al. Operability and chemotherapy responsiveness in advanced low-grade serous ovarian cancer. An analysis of the AGO Study Group metadatabase. Gynecol Oncol. 2016;140:457-62.
17. Gershenson DM, Sun CC, Bodurka D, Coleman LR, $\mathrm{Lu} \mathrm{KH}$, Sood AK, et al. Recurrent low-grade serous ovarian carcinoma is relatively chemoresistant. Gynecol Oncol. 20091;14:48-52.

18. Santillan A, Kim YW, Zahurak ML, Gardner GJ, Guintoli 2nd RL, Shih IM, et al. Differences of chemoresistance assay between invasive micropapillary/ lowgrade serous ovarian carcinoma and high-grade serous ovarian carcinoma. Int J Gynecol Cancer. 2007;17: 601-16.

19. Gershenson DM, Sun CC, Lu KH, Coleman RL, Sood AK, Malpica A, et al. Clinical behavior of stage II-IV low-grade serous carcinoma of the ovary. Obstet Gynecol. 2006;108(2):361-8.

20. Gershenson DM, Bodurka D, Coleman RL, Lu KH, Malpica A, Sun CC. Hormonal maintenance therapy for women with low-grade serous cancer of the ovary or peritoneum. J Clin Oncol. 2017;35:1103-11.

21. Fader AN, Bergstrom J, Jernigan A, Tanner 3th EJ, Roche KL, Stone RL, et al. Primary cytoreductive surgery and adjuvant hormonal monotherapy in women with advanced low-grade serous ovarian carcinoma: Reducing overtreatment without compromising survival? Gynecol Oncol. 2017;147:85-91.

22. Watson $\mathrm{CH}$, Secord AA. Durable response to hormonal therapy in a patient with rapidly progressive lowgrade serous ovarian cancer: A case report. Gynecol Oncol Reports 2020; https://doi.org/10.1016/j. gore.2020.100598

23. Gershenson DM, Sun CC, Iyer RB, Malpica AL, Kavanagh JJ, Bodurka DC, et al. Hormonal therapy for recurrent low-grade serous carcinoma of the ovary or peritoneum. Gynecol Oncol. 2012;125:661-6.

24. Tang M. O'Connell RL, Amant F, Beale P, McNally O, Sjoquist KM, et al. PARAGON: A phase II study of anastrozole in patients with estrogen receptor-positive recurrent/metastatic low-grade ovarian cancers and serous borderline ovarian tumors. Gynecol Oncol. 2019;154:531-8.

25. Gershenson DM. Low-grade serous carcinoma of the ovary or peritoneum. Ann of Oncol. 2016 (17):i45-i49.

26. Burger RA, Brady MF, Bookman MA, Fleming GF, Monk BJ, et al. Incorporation of bevacizumab in the primary treatment of ovarian cancer. N Engl J Med. 2011; 365(26):2473-83.

27. Perren TJ, Swart A-M, Pfisterer J, Ledermann JA, Pujade-Lauraine E, Kristensen G, et al. A phase 3 trial of bevacizumab in ovarian cancer. $\mathrm{N}$ Engl J Med. 2011;365:2484-96.

28. Aghajanian C, Blank SV, Goff BA, Judson PL, Teneriello MG, et al. OCEANS: A randomized, double-blind, placebo-controlled phase III trial of chemotherapy with or without bevacizumab in patients with platinum-sensitive recurrent epithelial ovarian, primary peritoneal, or fallopian tube cancer. J Clin Oncol. 2012; 30(17):2039-45.

29. Pujade-Lauraine E, Hilpert F, Weber B, Reuss A, Poveda A, Kristensen G, Sorio R, et al. Bevacizumab combined with chemotherapy for platinum-resistant re- 
current ovarian cancer: The AURELIA open-label randomized phase III trial. J Clin Oncol. 2014; 32(13):1302-8.

30. Bidus MA, Webb JC, Seidman JD, Rose GS, Boice CR, Elkas JC. Sustained response to bevacizumab in refractory well-differentiated ovarian neoplasms. Gynecol Oncol. 2006;102(1):5-7.

31. Schmeler KM, Tao X, Sun CC, Malpica A, Deavers M, Sood A, et al. Encouraging responses with bevacizumab in recurrent low-grade serous ovarian cancer. Proc ASCO. 2010; 28:15 (abstr \#e15503)).

32. Grisham RN, Iyer G, Sala E, Zhhou Qin, Iasons A, DeLair D, et al. Bevacizumab shows activity in patients with low-grade serous ovarian and primary peritoneal cancer. Int J Gynecol Cancer. 2014;24(6):1010-4.

33. Rose PG, Mahdi H, Jernigan A, Yang Bin. Activity of bevacizumab in patients with low-grade serous ovarian carcinoma. Int J GynecoL Cancer 2016;26:1048-52.

34. Dalton HJ, Fleming ND, Sun CC, Bhosale P, Schmeler KM, Gershenson DM. Activity of bevacizumab-containing regimens in recurrent low-grade serous ovarian or peritoneal cancer: A single institution experience. Gynecol Oncol. 2017;145(1):37-40.

35. Gershenson DM, Gourley C, Paul J. MEK inhibitors for the treatment of low-grade serous ovarian canver: Expanding therapeutic options for a rare ovarian cancer subtype. J Clin Oncol 2020. doi: 10.1200/ JCO.20.02190

36. Farley J, Brady WE, Vathipadiekal V, Lankes HA, Coleman R, Morgan MA, et al: Selumetinib in women with recurrent low-grade serous carcinoma of the ovary or peritoneum: An open-label, singlearm, phase 2 study. Lancet Oncol. 2014:134-40.

37. Monk BJ, Grisham RN, Banerjee S, Kalbacher E, Mirza MR, Romero I, et al: MILO/ENGOT-ov11: Binimetinib versus physician's choice chemotherapy in recurrent or persistent low-grade serous carcinomas of the ova- ry, fallopian tube, or primary peritoneum. J Clin Oncol 2020. doi:10.1200/JCO.20.01164

38. Gershenson DM, Miller A, Brady W, Paul J, Caty K, Rodgers W, et al: A randomized phase II/III study to assess the efficacy of trametinib in patients with recurrent or progressive low-grade serous ovarian or peritoneal cancer. Ann Oncol. 2019;30:851-934.

39. Fernandez ML, DiMattia GE, Dawson A, Bamford S, Anderson S, Hennessy BT, et al: Differences in MEK inhibitor efficacy in molecularly characterized lowgrade serous ovarian cancer cell lines. Am J Cancer Res. 2016;6:2235-51.

40. Mert I, Chhina J, Allo G, Dai J, Seward S, Carey MS, et al. Synergistic effect of MEK inhibitor and metformin combination in low grade serous ovarian cancer. Gynecol Oncol. 2017;146:319-26.

41. Milani A, Geuna E, Mittica G, Valabrega G. Overcoming endocrine resistance in metastatic breast cancer: current evidence and future directions. J Clin Oncol. 2014;5:990-1001.

42. Hortobagyi GN, Stemmer SM, Burris HA, Jap YS, Sonke GS, Paluch-Simon S, et al. Ribociclib as first-line therapy for HR-positive; advanced breast cancer. $\mathrm{N}$ Engl J Med. 2016;375:1738-48.

43. Finn RS, Martin M, Rugo HS, Jones S, Im SA, Gelmon $\mathrm{K}$, et al. Palbociclib and letrozole in advanced breast cancer. N Engl J Med 2016;375:1925-36.

44. Stephan J, Martin M, Di Leo A. MONARCH 3 final PFS: a randomized study of abemaciclib as initial therapy for advanced breast cancer. Npj Breast Cancer. 2019; DOI: 10.1038/s41523-018-0097-z

45. Colon-Otero G, Weroha SJ, Zanfagnin V, Foster NR, Asmus E, Wahner Hendrikson AE, et al. Results of a phase 2 trial of ribociclib and letrozole in patients with either relapsed estrogen receptor (ER) positive ovarian cancer or relapsed ER positive endometrial cancers. ASCO 2019 (abstract 5510)

Sažetak

\section{TERAPIJSKI PRISTUP SEROZNOM KARCINOMU JAJNIKA NISKOG GRADUSA}

\section{B. Petrić Miše i D. Šundov}

Niskogradusni serozni karcinom jajnika (LGSOC) manje je agresivan i ima bolji klinički ishod u usporedbi s visokogradusnim seroznim karcinomom jajnika (HGSOC). Kirurško liječenje s pokušajem maksimalne citoredukcije važno je i opravdano zbog relativne kemorezistencije ovog tumora. Stadije bolesti IA-IB trebalo bi klinički pratiti nakon primarne citoredukcije, dok su kliničko praćenje, kemoterapija ili hormonska terapija predložene mogućnosti za stadije bolesti IC-IIA. Bolesnice stadija IIB-IV liječe se kemoterapijom sastavljenom od karboplatina i paklitaksela tijekom 6 ciklusa koju slijedi hormonska terapija, najčešće inhibitorima aromataze, ili pak samom hormonskom terapijom do progresije bolesti ili neprihvatljive toksičnosti. Kirurško liječenje, kemoterapija i hormonska terapija također se koriste za bolesnice s povratom bolesti. U tijeku su klinička istraživanja ciljanom terapijom, posebno s inhibitorima mitogenom-aktiviranih proteinskih kinaza (MEK) i inhibitorima kinaza ovisnih o ciklinu (CDK). Dodatna istraživanja genomike LGSOC-a, u cilju boljeg definiranja aktivacije genskih mutacija uključenih u karcinogenezu, neophodna su radi poboljšanja prognoze ove zloćudne bolesti.

KLJUČNE RIJEČI: LGSOC, kemoterapija, hormonska terapija, ciljana terapija 